\title{
Variation in leaf functional traits of the Korean maple (Acer pseudosieboldianum) along an elevational gradient in a montane forest in Southern Korea
}

\author{
Ki Jung Nam ${ }^{1,2^{*}}$ (D) and Eun Ju Lee $3^{3 *}$
}

\begin{abstract}
Plant functional traits have been shown to be useful to understand how and why ecosystems and their components vary across environmental heterogeneity or gradients. This study investigated how plant functional (leaf) traits vary according to an elevation-associated environmental gradient. Environmental gradients (mean annual temperature and precipitation) were quantified, and leaf traits (leaf area, specific leaf area, leaf nitrogen, leaf phosphorus, leaf carbon, and leaf $\mathrm{C} / \mathrm{N}$ ratio) of the understory woody plant species Acer pseudosieboldianum were examined across an elevational gradient ranging from 600 to $1200 \mathrm{~m}$ in a Baegunsan Mountain in Gwangyang-si, Jeollanam-do, South Korea. The results showed that mean annual temperature and precipitation decreased and increased along with elevation, respectively. Leaf area of the plant species decreased slightly with increasing elevation, while specific leaf area did not differ significantly. Leaf nutrients (nitrogen, phosphorus, and carbon concentrations) were higher at high elevations, but leaf C/N ratio decreased with elevation.
\end{abstract}

Keywords: Altitudinal gradient, Environmental filtering, Functional traits, Leaf nitrogen, Specific leaf area

\section{Backgrounds}

Plant "functional traits," which are individual's morphological or physiological features relevant to survival, growth, and reproduction, are considered primary drivers of species interaction, community assembly, and species diversity (Roscher et al. 2012; Kunstler et al. 2015). These traits can affect the way plant individual interact with other plants or organisms in other trophic levels, which determine patterns of species interactions in a community (Perez-Hargundegy et al. 2013). It is often considered that community assembly is determined by environmental filtering and the survival of a species through the filtering is largely related to functional characteristics or traits of the species (Hulshof and Swenson 2010).

\footnotetext{
*Correspondence: prin225@gnu.ac.kr; ejlee@snu.ac.kr

${ }^{1}$ Department of Biology Education, Gyeongsang National University, Jinju 52828, Republic of Korea

${ }^{3}$ School of Biological Sciences, Seoul National University, Seoul 08826, Republic of Korea

Full list of author information is available at the end of the article
}

Also, these functional traits are considered as useful proxies to understand how and why ecosystems and their components vary across environmental heterogeneity or gradients (Garnier and Navas 2011). For instance, key functional traits such as plant size or leaf traits (mass per unit area or leaf stoichiometry) appear to correlate strongly with whole-plant performance, so these traits can be utilized to understand variation in plant function and diversity (Reich et al. 1997; West et al. 1999; Westoby et al. 2002). Individual plasticity in a tolerance against abiotic stresses can greatly influence the responses of a plant community to environmental changes, so functional traits of individual species in a community may act as a useful indicator for assessing and predicting variation in community responses to environmental changes (Mouillet et al. 2010).

Elevational gradients in mountain systems have been occasionally utilized as an experimental setting to test the stress-gradient hypothesis (Schob et al. 2013). It is generally assumed that higher elevations are more stressful for plants and this physical stress at high 
elevations is thought to be primarily caused by low air temperature, low partial pressure of $\mathrm{CO}_{2}$, and high UV radiation, along with thin soils and low nutrient availability (Korner 2007; Huber et al. 2007). Altitudinal differences in environmental conditions can be utilized as space for time substitutions to predict potential responses of plant traits to future climate change (Pfenningwerth et al. 2017). Performance-related foliar plant traits are thought to be highly sensitive to climatic environments and may co-vary with climatic variation associated with elevational gradient (Pratt and Mooney 2013; Read et al. 2014).

Until recently, considerable amounts of research has been conducted on community structure and diversity of plant species in mountain ecosystems in South Korea (for instance, Park et al. 2003; Choo and Kim 2005; Lee et al. 2013). However, most of them are taxonomy-based and trait-based approach has not been applied. Accordingly, information on variation in plant functional traits across various environmental gradients is not available. Therefore, in the present study, foliar functional traits of plant species Acer pseudosieboldianum were investigated along elevation ranging from 600 to $1200 \mathrm{~m}$ to understand how functional traits (leaf traits) vary across elevation-associated environmental gradient.

\section{Materials and method}

\section{Study area and focal species}

This study was conducted in Baegunsan mountain $\left(35^{\circ}\right.$ $6^{\prime} \mathrm{N}, 127^{\circ} 37^{\prime} \mathrm{E}$ ) in Gwangyang-si, Jeollanam-do province, South Korea. Mean annual temperature and yearly precipitation of this area are $13^{\circ} \mathrm{C}$ and $1271.5 \mathrm{~mm}$ respectively (based on 2017 averaged data from Baegunsan observation station at $515 \mathrm{~m}$ in altitude). The study area is characterized by deciduous trees such as Quercus mongolica, Carpinus laxiflora, Quercus variabilis, Quercus serrata, Exochorda serratifolia, and Stewartia pseudocamellia (Kim and Jeong 2015).

Acer pseudosieboldianum is a deciduous small tree or shrub, native to Korea. Although this species is not a dominant tree in the study area, it occupies across the entire elevation gradient in the study area, and most individuals have similar height $(1.5 \sim 2 \mathrm{~m})$ (their ages were not estimated but may be not mature yet considering their heights); therefore, the variation in leaf traits between individuals resulting from difference in height and light availability may be considered minimal.

\section{Environmental gradient quantification}

Mean annual temperature and yearly precipitation across elevation in the study area were estimated using data from the Korea Meteorological Administration. As data specific for each elevation gradient in the study area were not available, data (for between January and
December 2017) from 22 weather observation stations located in Jeolla- and Gyeongsang-do province, at similar latitudes but various altitudes, were obtained and temperature and precipitation values were regressed against altitude to determine the relationship.

\section{Plant sampling and leaf trait measurements}

Sampling sites were selected for every $100 \mathrm{~m}$ in altitude across the elevation gradient (from 700 to $1200 \mathrm{~m}$ in altitude) on one west-facing slope of the Sangbong peak $\left(1222.2 \mathrm{~m}, 35^{\circ} 6^{\prime} \mathrm{N}, 127^{\circ} 37^{\prime} \mathrm{E}\right)$ of the Baegunsan mountain. At each sampling site, 4-10 individuals of the $A$. pseudosieboldianum tree of similar height (approximately $1.5 \sim 2 \mathrm{~m}$ ) were randomly chosen. The numbers of trees sampled at each sampling site were determined depending on the availability of individuals on site. From each individual, five fully expanded, non-senescent leaves from multiple branches were collected. Leaves showing any noticeable symptoms of herbivore attack were avoided. Sampling was conducted from late May to early June in 2018.

Collected leaves (on a branch) were sealed in a closed plastic bag and taken to the laboratory, then immediately scanned using an electronic scanner, or stored in a fridge $\left(4{ }^{\circ} \mathrm{C}\right)$ for no more than $12 \mathrm{~h}$ until scanning. From scanned images, leaf area, LA $\left(\mathrm{mm}^{2}\right)$, was calculated using ImageJ (Rueden et al. 2017). Scanned leaves were dried in a dry oven at $80^{\circ} \mathrm{C}$ for $48 \mathrm{~h}$, and then weighted to obtain leaf dry mass. To calculate specific leaf area, SLA $\left(\mathrm{mm}^{2} \mathrm{mg}^{-1}\right)$, the ratio between fresh leaf area and leaf dry mass, areas, and dry mass of five leaves of an individual tree were pooled.

For leaf nutrient analysis, dried leaves were powdered using a mortar and pestle and homogenized. For leaf $\mathrm{P}$, ground leaves were digested using $\mathrm{HNO}_{3}$ in a microwave oven and analyzed with an inductively coupled plasma-optical emission spectrometer (ICP-OES) (OPTIMA 730DV, PerkinElmer, USA). For leaf $\mathrm{N}$ and $\mathrm{C}$, leaf powder was analyzed using a micro elemental analyzer (Flash 2000, Thermo Fisher Scientific, USA). Total C and N contents were reported as percentage of dry mass (\%).

\section{Soil measurements}

For characterizing soil features of each sampling site, three soil samples were taken at random from the 0-10 $\mathrm{cm}$ soil layer of each sampling site (except for the site at the lowest elevation) using a hand shovel and transferred to the laboratory. After homogenization, soil samples were air dried and sieved with 2-mm mesh for further analysis. Total soil $\mathrm{N}$ (\%) were determined using Kjeldahl analysis. $\mathrm{NH}_{3}-\mathrm{N}$ and $\mathrm{NO}_{3}-\mathrm{N}$ were estimated via colorimetric titration after the extraction with $2 \mathrm{M} \mathrm{KCl}$ solution and following Kjeldahl distillation. Available P was determined with Lancaster extraction method. Soil 
organic matter (\%) was determined with Walkley-Black titration. Soil $\mathrm{pH}$ was measured with a $\mathrm{pH}$ meter.

\section{Data analysis}

Linear regression was performed between elevation ( $\mathrm{m}$ a.s.l) and all measured soil and leaf variables (soil: total $\mathrm{N}$, $\mathrm{NH}_{3}-\mathrm{N}, \mathrm{NO}_{3}-\mathrm{N}$, organic matter, $\mathrm{pH}$; leaf: LA, SLA, total $\mathrm{N}$, total $\mathrm{C}$, total $\mathrm{P}, \mathrm{C} / \mathrm{N}$ ratio). For soil available $\mathrm{P}$, quadratic regression was applied as this model explained variation of the data slightly better than linear regression model $(p=$ 0.047 at $F$-test). All analyses were performed with the $\mathrm{R}$ software 3.5.0 (R Development Core Team 2011).

\section{Results and discussion}

There was a significant linear correlation between mean annual temperature or yearly precipitation and elevation. As elevation increased, mean annual temperature decreased but yearly precipitation increased (Fig. 1). The results are not surprising as altitudinal decrease in temperature is well-known phenomenon despite temperature lapse rates for particular areas especially mountain regions may vary depending on microclimate of the area (Minder et al. 2010). Also, it is generally accepted that precipitation in mountain areas depends on altitude and mostly increases with increasing elevation despite considerable spatial variations (Sokol and Bliznk 2009).

As for soil characteristics, in the present study, there was no distinct pattern for soil nitrogen concentrations (either total $\mathrm{N}, \mathrm{NH}_{3}-\mathrm{N}$, or $\mathrm{NO}_{3}-\mathrm{N}$ ) along elevation (Fig. 2a, b, c). Also, no significant correlation between soil organic matter concentrations and elevation was found (Fig. 2d). The results are generally comparable to results of Huber et al. (2007). However, in many cases, it has been reported that $\mathrm{N}$ stock increases with elevation, which has been attributable to the decline in temperature which decreases $\mathrm{N}$ mineralization rate so that more $\mathrm{N}$ can be retained in soil (Hart and Perry 1999; Tashi et al. 2016; Qasba et al. 2017). The stock and turnover of soil organic matter are known to be influenced by many soil-forming factors such as climate, topography, vegetation, or parent material, and it is generally thought that climate is the most important regulator (Alvarez and Lavado 1998; Dai and Huang 2006). Changes in climate along altitudinal gradients can affect the composition and productivity of vegetation, which in turn influences the concentration of soil organic matter. Soil water balance, erosion, and geographic deposition process also vary along altitude, all of which may cause altitudinal variation in soil organic matter (Quideau et al. 2001; Tan et al. 2004). In many cases, positive correlations between altitude and soil organic matter have been found. In the present study, nonlinear relationship between soil available phosphorus and altitude was found, with the lowest figure at the middle elevation (900 1000 m) (Fig. 2e). Soil pH increased with altitude (Fig. 2f). Similar results have been reported in $\mathrm{He}$ et al. (2016) in which they speculated that nonlinear relationship between soil $\mathrm{P}$ and elevation may be caused by nonlinear changes in soil water content, $\mathrm{pH}, \mathrm{P}$ sorption capacity, and interactions among microclimate, topography, and vegetation.

Leaf area decreased significantly with elevation, while specific leaf area (SLA) did not differ (Fig. 3a, b). These results are comparable with results of several studies (Velazquez-Rosas and Meave 2002; Pfennigwerth et al. 2017). In Velazquez-Rosas and Meave (2002), the decrease in leaf area along elevation was associated with temperature reduction and low soil fertility. Low
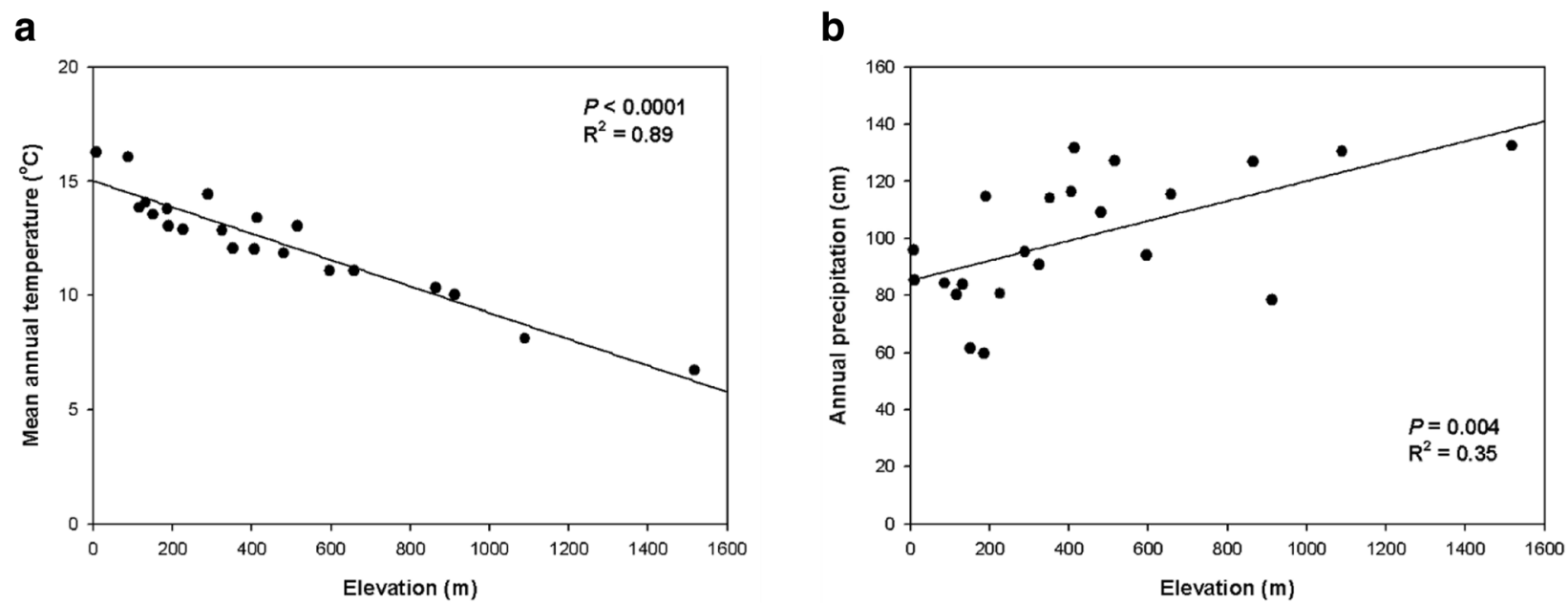

Fig. 1 a Mean annual temperature $\left({ }^{\circ} \mathrm{C}\right)$ and $\mathbf{b}$ yearly precipitation $(\mathrm{cm})$ along the elevation gradient in the study area (estimated from data of 22 observation stations at similar latitudes and various altitude). Regression coefficients (R (Atkin et al. 2006)) and $P$ values are given for linear model regressions 

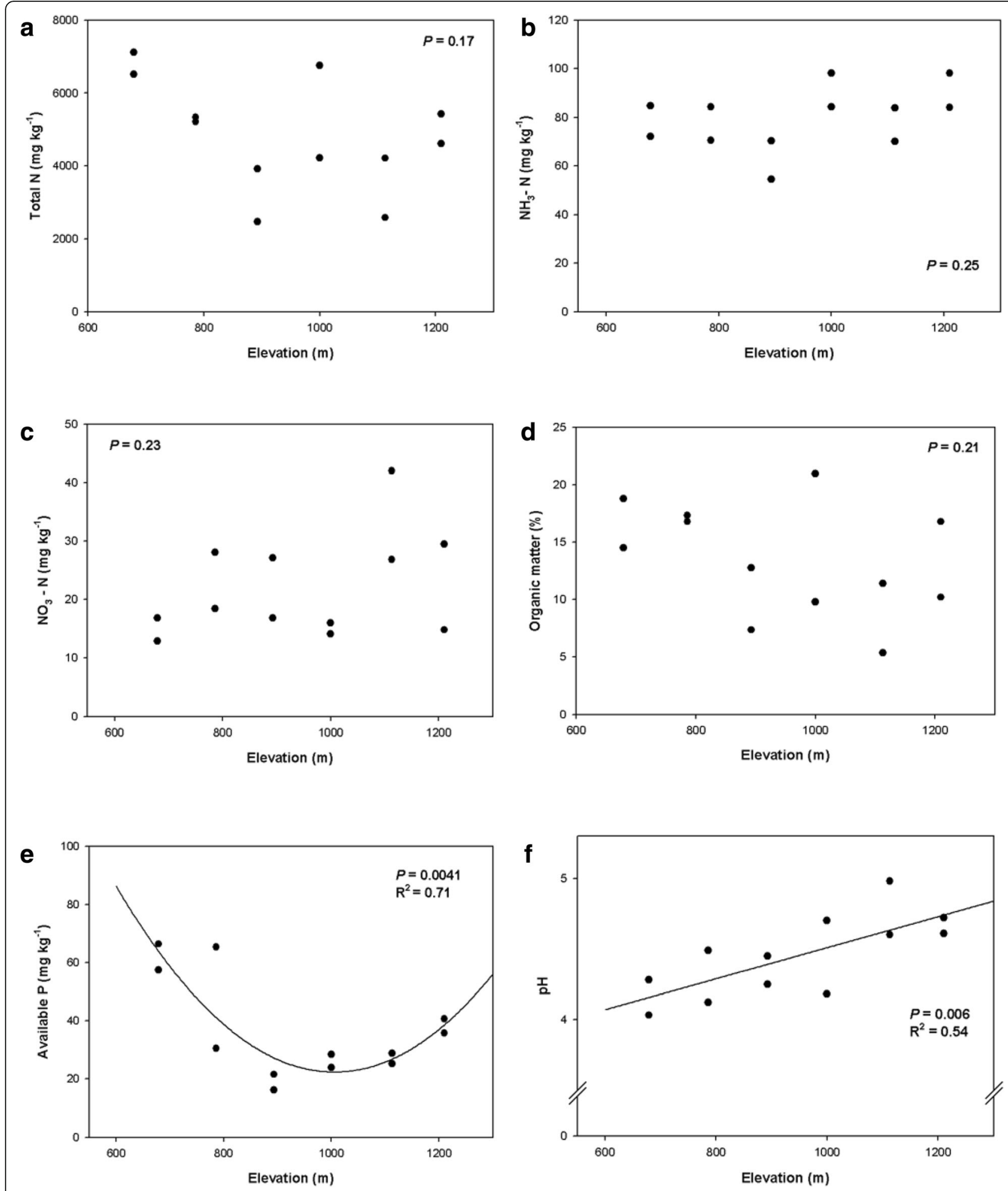

Fig. 2 Soil characteristics of the sampling sites along the elevation gradient. a Total $\mathrm{N}, \mathbf{b} \mathrm{NH}_{3}-\mathrm{N}, \mathbf{c} \mathrm{NO}_{3}-\mathrm{N}$, $\mathbf{d}$ organic matter, e available $\mathrm{P}$, and $\mathbf{f}$ pH. Regression coefficients ( $R$ (Atkin et al. 2006)) and $P$ values are given for $\mathbf{e}$ and $\mathbf{f}$

temperature reduces cell growth, which results in overall decrease in leaf size (Leigh 1975). Low soil fertility specifically low soil $\mathrm{N}$ at high elevations can cause small leaves which are thought to be morphological adaptation for nutrient conservation (Tanner et al. 1998). However, in the present study, soil $\mathrm{N}$ did not differ along 

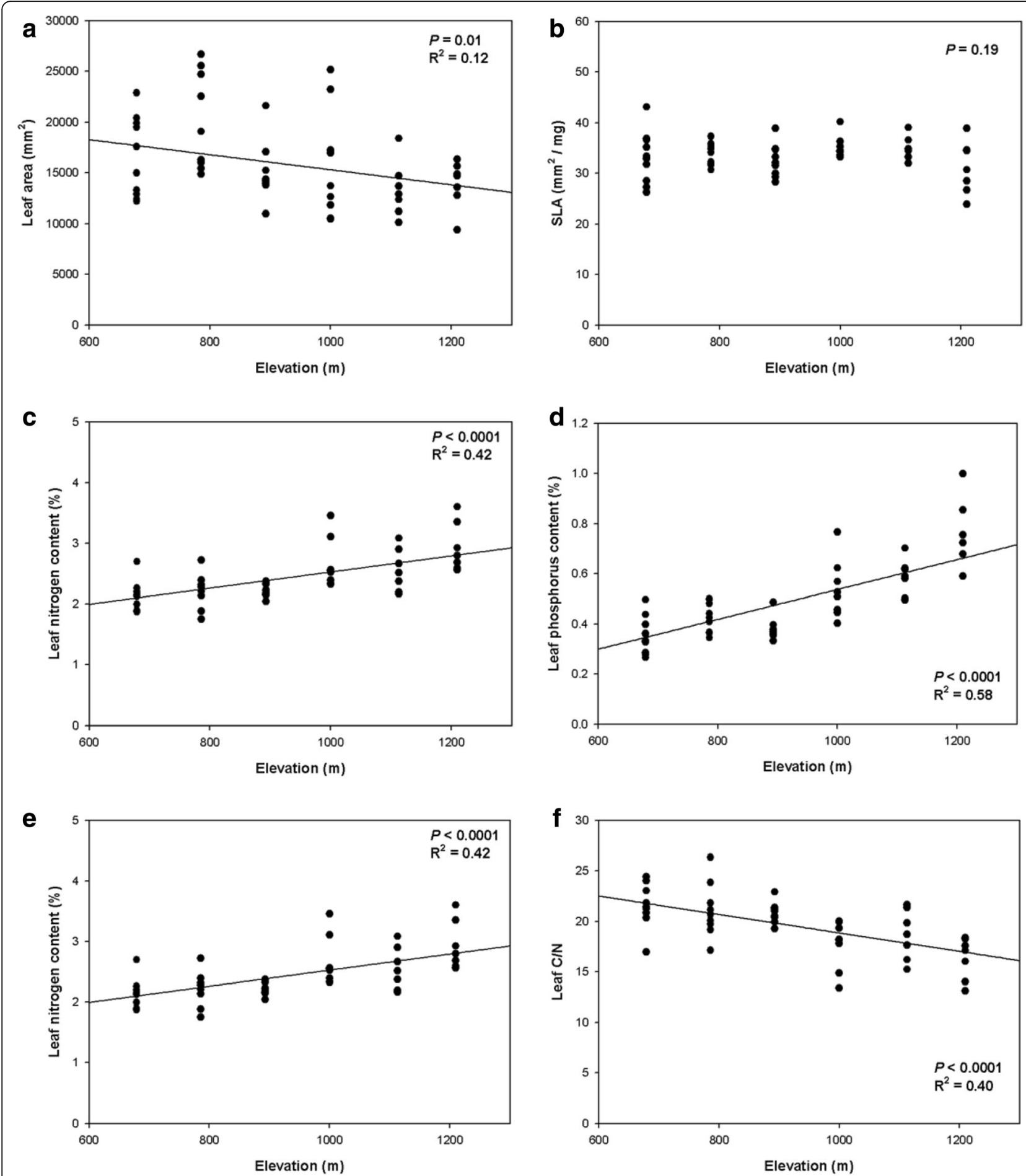

Fig. 3 a Leaf area $\left(\mathrm{mm}^{2}\right)$, b specific leaf area $\left(\mathrm{mm}^{2} \mathrm{mg}^{-1}\right)$, c leaf nitrogen content (\%), d leaf phosphorus content (\%), e leaf carbon content (\%), and $\mathbf{f}$ leaf $\mathrm{C} / \mathrm{N}$ ratio of Acer pseudosieboldianum along the elevation gradient in the study area. Regression coefficients (R (Atkin et al. 2006)) and $P$ values are given for linear models with slopes showing a significant difference from zero

elevation. As for SLA, the decrease in SLA along elevation has also been reported in other studies (Poorter et al. 2009; Bresson et al. 2011). It has been suggested that low temperature limits cell expansion which leads to a large number of small cells per unit area and more cell wall and cell layers per unit area, which results in decrease in SLA (Atkin et al. 2006; Poorter et al. 2009). In the present study, SLA did not differ along elevation. 
The result could be due to high intraspecific variability in SLA which may obscure a correlation between SLA and temperature. In Rosbakh et al. (2015), a correlation between SLA and temperature was observed in a few species but not many (only 3 of 22), while strong positive correlation between SLA and temperature was observed at community level.

Leaf nutrient concentrations (nitrogen, phosphorus, carbon) increased significantly along an elevational gradient (Fig. 3c, d, e). Leaf $\mathrm{C} / \mathrm{N}$ ratio decreased with elevation (Fig. 3f). The results of the present study are consistent with other studies. It has been reported that plants at higher elevations have lower growth rates and higher leaf nutrient content per unit area (Pfennigwerth et al. 2017). In some area, nitrogen deposition increased with elevation, which caused high plant nitrogen concentrations (Fowler et al. 1988). In Morecroft and Woodward (1996), increases in leaf nitrogen and phosphorus concentrations along elevation were observed, and the results were associated with decreases in leaf biomass (mainly carbon). In the present study, carbon concentration increased with elevation but leaf $\mathrm{C} / \mathrm{N}$ ratio decreased, which may suggest the partial support for the hypothesis in Morecroft and Woodward (1996). It is to note that there are also studies showing the decrease in leaf nitrogen and phosphorus (Soethe et al. 2008; Zhao et al. 2016). The acquisition of nitrogen and phosphorus in plants is known to be influenced by climate, soil conditions, phylogeny, and different physiological growth strategies among species, and the pattern of nitrogen and phosphorus in leaf may reflect variation in climate, soil nutrient, and plant growth form along elevation (Zhao et al. 2016).

\section{Conclusion}

In the present study, key leaf functional traits (leaf area, SLA, nutrients) of understory woody plant species Acer pseudosieboldianum varied along elevation, with some traits increased and others decreased. Plant communities usually consist of a variety of plant species with ranges of functional traits; therefore, means of variation in those traits are often utilized to understand functional features of plant communities. The results of the present study suggest that variation in functional traits at within-species level may have significant impacts on overall feature of functional traits, so intraspecific variation of individual plant species needs to be considered.

\section{Abbreviations}

ICP-OES: Inductively coupled plasma-optical emission spectrometer; LA: Leaf area; SLA: Specific leaf area

Acknowledgements

Not applicable

\section{Funding}

This research was supported by the Basic Science Research Program through the National Research Foundation of Korea (NRF) funded by the Ministry of Science, ICT and Future Planning (NRF-2015R1C1A1A01053841), (2017-0994).

Availability of data and materials

Please contact author for data requests.

\section{Authors' contributions}

KJN designed the study, carried out sampling, laboratory analysis and drafted the manuscript. EJL participated in the design of the study, participated in the laboratory analysis, and performed the statistical analysis. All authors read and approved the final manuscript.

\section{Ethics approval and consent to participate}

Not applicable

\section{Consent for publication}

Not applicable

\section{Competing interests}

Both authors declare that they have no competing interests.

\section{Publisher's Note}

Springer Nature remains neutral with regard to jurisdictional claims in published maps and institutional affiliations.

\section{Author details}

${ }^{1}$ Department of Biology Education, Gyeongsang National University, Jinju 52828 , Republic of Korea. ${ }^{2}$ Institute of Agriculture and Life Science, Gyeongsang National University, Jinju 52828, Republic of Korea. ${ }^{3}$ School of Biological Sciences, Seoul National University, Seoul 08826, Republic of Korea.

Received: 19 November 2018 Accepted: 30 November 2018

Published online: 18 December 2018

\section{References}

Alvarez R, Lavado RS. Climate, organic matter and clay content relationships in the pampa and Chaco soils, Argentina. Geoderma. 1998;83:127-41.

Atkin OK, Loveys BR, Atkinson LJ, Pons TL. Phenotypic plasticity and growth temperature: understanding interspecific variability. J Exp Bot. 2006;57:267-81.

Bresson C, Vitasse Y, Kremer A, Delzon S. To what extent is altitudinal variation of functional traits driven by genetic adaptation in European oak and beech? Tree Physiol. 2011;31:1164-74

Choo GC, Kim GT. Vegetation structure of mountain ridge from Bubong to Poamsan in Baekdudaegan, Korea. Korean J Environ Ecol. 2005;19:83-9.

Dai W, Huang Y. Relation of soil organic matter concentration to climate and altitude in zonal soils of China. Catena. 2006;65:87-94.

Fowler D, Cape JN, Leith ID, Choularton TW, Gay MJ, Jones A. The influence of altitude on rainfall composition at Great Dun Fell. Atmos Environ. 1988;22:1355-62.

Garnier E, Navas M. A trait-based approach to comparative functional plant ecology: concepts, methods and applications for agroecology. A review. Agron Sustain Dev. 2011;32:365-99.

Hart SC, Perry DA. Transferring soils from high- to low-elevation forests increases nitrogen cycling rates: climate change implications. Glob Chang Biol. 1999;5:23-32.

He X, Hou E, Liu Y, Wen D. Altitudinal patterns and controls of plant and soil nutrient concentrations and stoichiometry in subtropical China. Scientific Report. 2016;6:24261.

Huber E, Wanek W, Gottfried M, Pauli H, Schweiger P, Arndt SK, Reiter K, Richter A. Shift in soil-plant nitrogen dynamics of an alpine-nival ecotone. Plant Soil. 2007;301:65-76.

Hulshof C, Swenson NG. Variation in leaf functional trait values within and across individuals and species: an example from a Costa Rican dry forest. Funct Ecol. 2010;24:1365-2435.

Kim IT, Jeong SH. $4^{\text {th }}$ Natural Environmental Survey (Jeonnam01). Ministry of Environment of Korea: National Institute of Ecology; 2015.

Korner C. The use of 'altitude' in ecological research. Trends Ecol Evol. 2007;22:569-74.

Kunstler J, Falster D, Cooms DA, Hui F, Kooyman RM, Laughlin DC, Pooter L, Vanderwel M, Vieilledent G, Wright SJ, Aiba M, Baraloto C, Caspersen J, Cornelissen JHC, Gourlet-Fleury S, Hanewinkel M, Herault B, Kattge J, Kurokawa H, Onoda Y, Peñuelas J, Poorter H, Uriarte M, Richardson S, Ruiz- 
Benito PIFS, Ståhl G, Swenson NG, Thompson J, Westerlund B, Wirth C, Zavala ZA, Zeng H, Zimmerman JK, Zimmermann NE, Westoby M. Plant functional traits have globally consistent effects on competition. Nature. 2015;2:16476.

Lee CB, Chun JH, Song HK, Cho HJ. Altitudinal patterns of plant species richness on Baekdudaegan Mountain, South Korea: mid-domain effect, area, climate, and Rapoport' rule. Ecol Res. 2013;28:67-79.

Leigh EG. Structure and climate in tropical rain forest. Annu Rev Ecol Syst. 1975;6:67-86.

Minder JR, Mote PW, Lundquist JD. Surface temperature lapse rates over complex terrain: lessons from the Cascade Mountains. J Geophys Res Atmos. 2010;115: D14112.

Morecroft MD, Woodward Fl. Experiments on the causes of altitudinal differences in the leaf nutrient contents, size and $813 \mathrm{C}$ of Alchemilla alpina. New Phytol. 1996;134:471-9.

Mouillet D, Graham NAJ, Villeger S, Mason NWH, Bellood DR. A functional approach reveals community responses to disturbances. Trends Ecol Evol. 2010;28(3):167-77.

Park IH, Seo YK, Choi YC. Forest structure in relation to slope aspect and altitude in valley forests at Baraebong, Jirisan National Park. Korean J Environ Ecol. 2003; 16:449-56

Pérez-Harguindeguy N, Díaz S, Garnier E, Lavorel A, Poorter H, Jaureguiberry P, BretHarte MS, Cornwell WK, Craine JM, Gurvich DE, Urcelay C, Veneklaas EJ, Reich PB, Poorter L, Wright IJ, Ray P, Enrico L, Pausas JG, de Vos AC, Buchmann N, Funes G, Quétier F, Hodgson JG, Thompson K, Morgan HD, ter Steege H, van der Heijden MGA, Sack L, Blonder B, Poschlod P, Vaieretti MV, Conti G, Staver AC, Aquino S, Cornelissen JHC. New handbook for standardised measurement of plant functional traits worldwide. Aust J Bot. 2013;61:167-234.

Pfennigwerth AA, Bailey JK, Schweitzer JA. Trait variation along elevation gradients in a dominant woody shrub is population-specific and driven by plasticity. AoB Plants. 2017;9:plx027.

Poorter H, Niinemets U, Poorter L, Wright IJ, Villar R. Causes and consequences of variation in leaf mass per area (LMA): a meta-analysis. New Phytol. 2009;182:565-88.

Pratt JD, Mooney KA. Clinal adaptation and adaptive plasticity in Artemisia californica: implications for the response of a foundation species to predicted climate change. Glob Chang Biol. 2013;19:2454-66.

Qasba S, Masoodi TH, Bhat SJA, Paray PA, Bhat A, Khanday MUD. Effect of altitude and aspect on soil physico-chemical characteristics in Shankaracharya reserved forest. Int J Pure Appl Biosci. 2017;5:585-96.

Quideau SA, Chadwick QA, Benesi A, Graham RC, Anderson MA. A direct link between forest vegetation type and soil organic matter composition. Geoderma. 2001;104:41-60.

R Development Core Team. R: A language and environment for statistical computing. Vienna: R Foundation for Statistical Computing; 2011.

Read QD, Moorhead LC, Swenson NG, Bailey JK, Sanders NJ. Convergent effects of elevation on functional leaf traits within and among species. Funct Ecol. 2014;28:37-45.

Reich P, Walters MB, Ellsworth DS. From tropics to tundra: global convergence in plant functioning. Proc Natl Acad Sci, USA. 1997;94:13730-4.

Rosbakh S, Romermann C, Psochlod P. Specific leaf area correlates with temperature: new evidence of trait variation at the population, species and community levels. Alp Bot. 2015;125:79-86.

Roscher C, Schumacher J, Gubsch M, Lipowsky A, Weigelt A, Buchmann N, Schmid B, Schulze ED. Using plant functional traits to explain diversityproductivity relationships. PLoS One. 2012;7(5):e36760.

Rueden $C T$, Schindelin J, Hiner MC, DeZonia BE, Walter AE, Arena ET, Eliceiri KW. ImageJ2: ImageJ for the next generation of scientific image data. BMC Bioinformatics. 2017:18:529.

Schob C, Armas C, Guler M, Prieto I, Pugnaire FI. Variability in functional traits mediates plant interactions along stress gradients. J Ecol. 2013;101:753-62.

Soethe N, Lehmann J, Engels C. Nutrient availability at different altitudes in a tropical montane forest in Ecuador. J Trop Ecol. 2008;24:397-406.

Sokol Z, Bliznk V. Areal distribution and precipitation-altitudinal relationship of heavy short-term precipitation in the Czech Republic in the warm part of the year. Atmos Res. 2009;94:652-62.

Tan ZX, lal R, Smeck NE, Calhoun FG. Relationships between surface soil organic carbon pool and site variables. Geoderma. 2004;121:185-7.

Tanner EVJ, Vitousek PM, Cuevas E. Experimental investigation of nutrient limitation of forest growth on wet tropical mountains. Ecology. 1998;79:10-22.

Tashi S, Singh B, Keitel C, Adams M. Soil carbon and nitrogen stock in forests along an altitudinal gradient in the eastern Himalayas and a meta-analysis of global data. Glob Chang Biol. 2016;22:2255-68.
Velazquez-Rosas N, Meave J. Elevational variation of leaf traits in montane rain forest tree species at La Chinantla, Southern Mexico. Biotropica. 2002;34:534-46.

West GB, Brown JH, Enquist BJ. A general model for the structure and allometry of plant vascular systems. Nature. 1999;400:664-7.

Westoby M, Falster DS, Moles AT, Vesk PA, Wright IJ. Plant ecological strategies: some leading dimensions of variation between species. Annu Rev Ecol Syst. 2002;33:125-59.

Zhao N, Yu G, He N, Xia F, Wang Q, Wang R, Xu Z, Jia Y. Invariant allometric scaling of nitrogen and phosphorus in leaves, stems, and fine roots of woody plants along an altitudinal gradient. J Plant Res. 2016;129:647-57.
Ready to submit your research? Choose BMC and benefit from:

- fast, convenient online submission

- thorough peer review by experienced researchers in your field

- rapid publication on acceptance

- support for research data, including large and complex data types

- gold Open Access which fosters wider collaboration and increased citations

- maximum visibility for your research: over $100 \mathrm{M}$ website views per year

At BMC, research is always in progress.

Learn more biomedcentral.com/submissions 